\title{
Enhanced Catalytic Activity for Methane Combustion through In-Situ Water Sorption
}

\author{
Weixin Huang ${ }^{\mathrm{a}}$, Xinrui Zhang ${ }^{\mathrm{b}}$, An-Chih Yang ${ }^{\mathrm{a}}$, Emmett D. Goodman ${ }^{\mathrm{a}}$, Kun-Che Kao ${ }^{\mathrm{a}}$ \\ and Matteo Cargnello, ${ }^{\mathrm{a}}$ * \\ ${ }^{a}$ Department of Chemical Engineering and SUNCAT Center for Interface Science and \\ Catalysis, Stanford University, Stanford, California 94305, USA \\ ${ }^{b}$ Department of Materials Science and Engineering, Stanford University, Stanford, \\ California 94305, USA \\ *corresponding author: mcargnello@stanford.edu
}

\section{Content:}

1. Figures S1-S12

2. Tables S1-S4

3. The calculation of Gibbs free energy change

4. The calculation of $\mathrm{PdO}$ and $\mathrm{CaO}$ surface adsorptive sites 


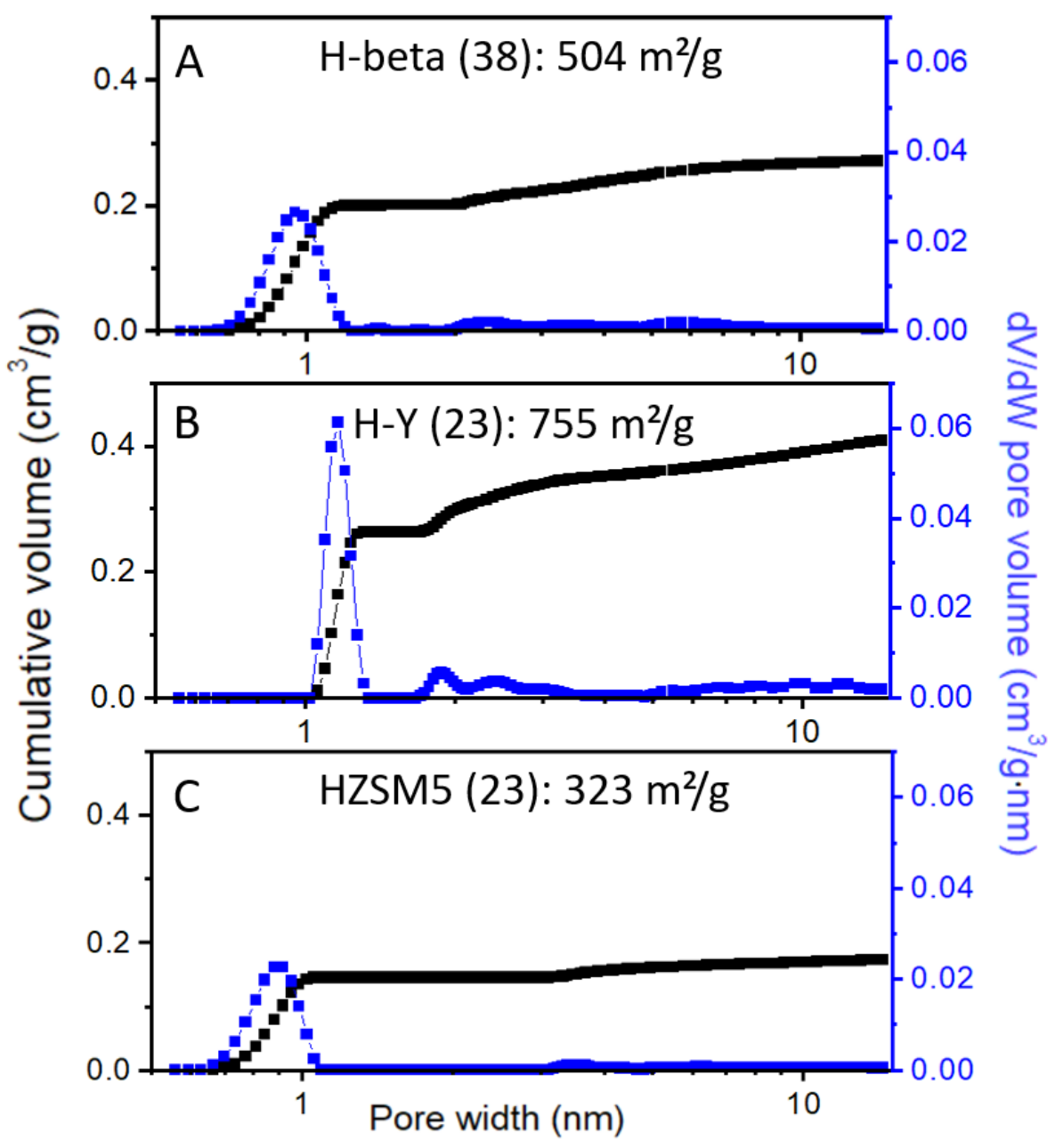

Figure S1. DFT pore size distributions of (A) H-Beta, (B) H-Y and (C) H-ZSM5. 


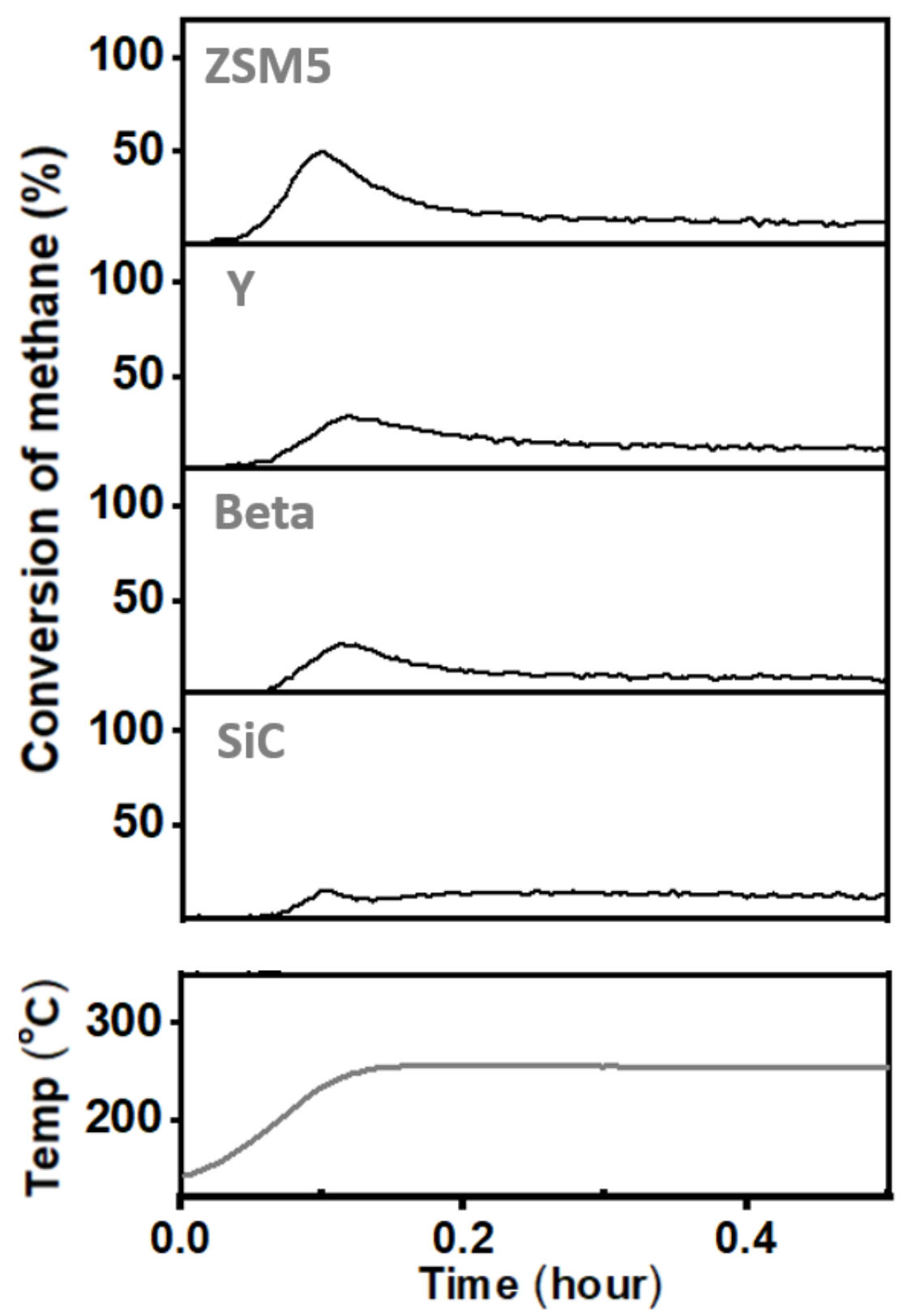

Figure S2. Methane conversion over $\mathrm{Pd} / \mathrm{CeO}_{2}$ diluted with $\mathrm{SiC}$, H-Beta, $\mathrm{H}-\mathrm{Y}$ and $\mathrm{H}-\mathrm{ZSM} 5$ up to $250{ }^{\circ} \mathrm{C}$. The catalysts were pretreated in situ at $500{ }^{\circ} \mathrm{C}$ before reaction. 

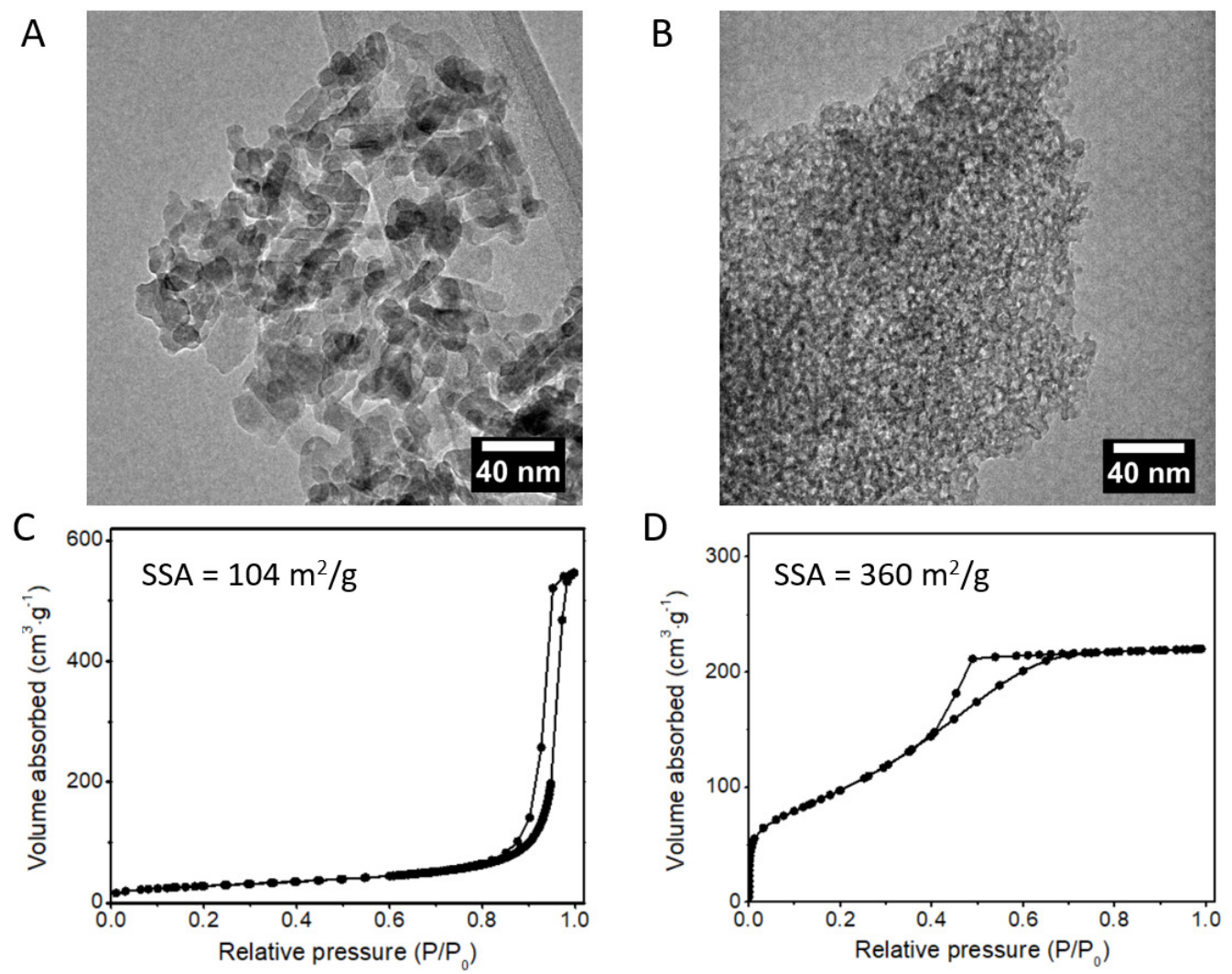

Figure S3. TEM images and $\mathrm{N}_{2}$-physisorption isotherm of (A and C) low-surface-area $\mathrm{Al}_{2} \mathrm{O}_{3}$ and $(\mathrm{B}$ and $\mathrm{D})$ high-surface-area $\mathrm{Al}_{2} \mathrm{O}_{3}$. 


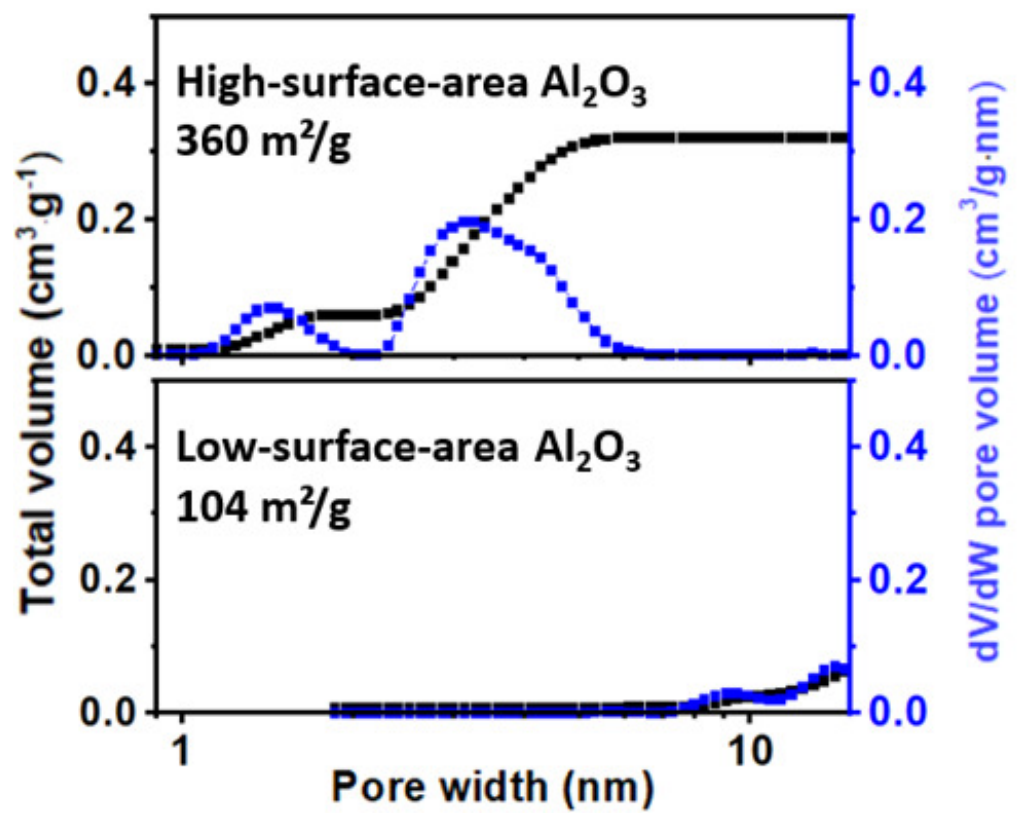

Figure S4. DFT pore size distributions of low-surface-area and high-surface-area $\mathrm{Al}_{2} \mathrm{O}_{3}$. 

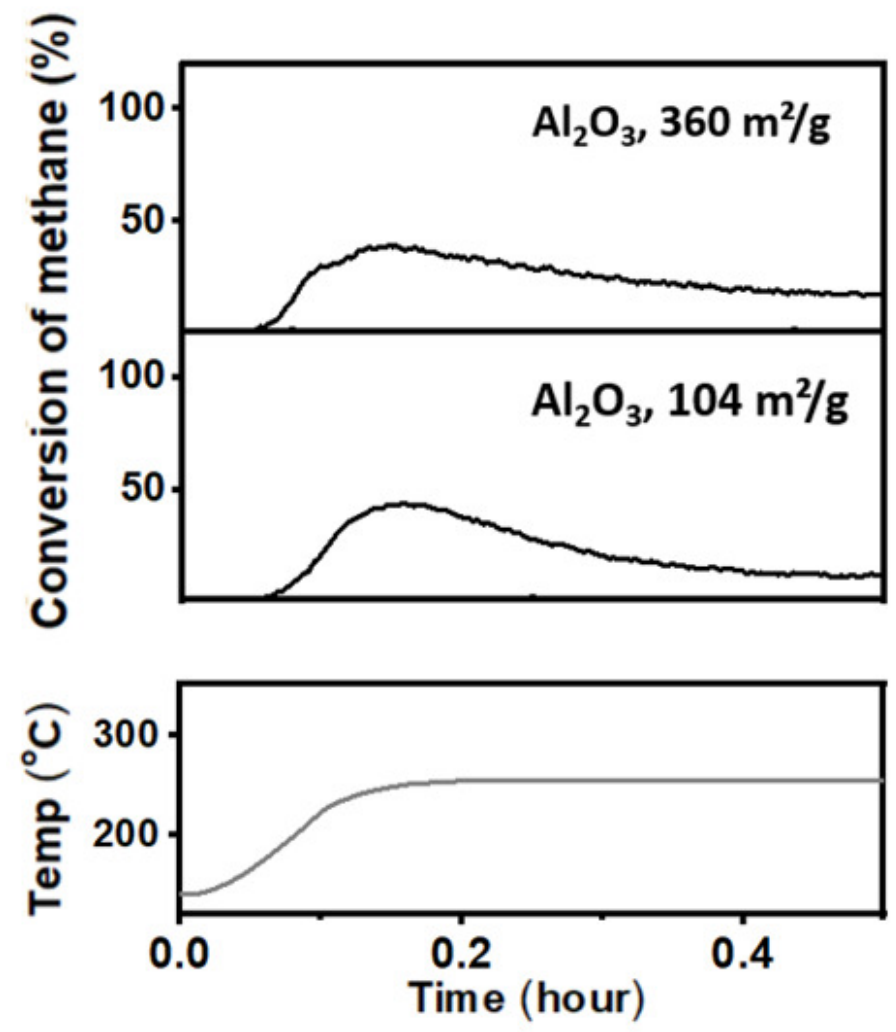

Figure S5. Methane conversion over $\mathrm{Pd} / \mathrm{CeO}_{2}$ diluted with low-surface-area and highsurface-area $\mathrm{Al}_{2} \mathrm{O}_{3}$ up to $250{ }^{\circ} \mathrm{C}$. The catalysts were pretreated at $500{ }^{\circ} \mathrm{C}$ before reaction. 

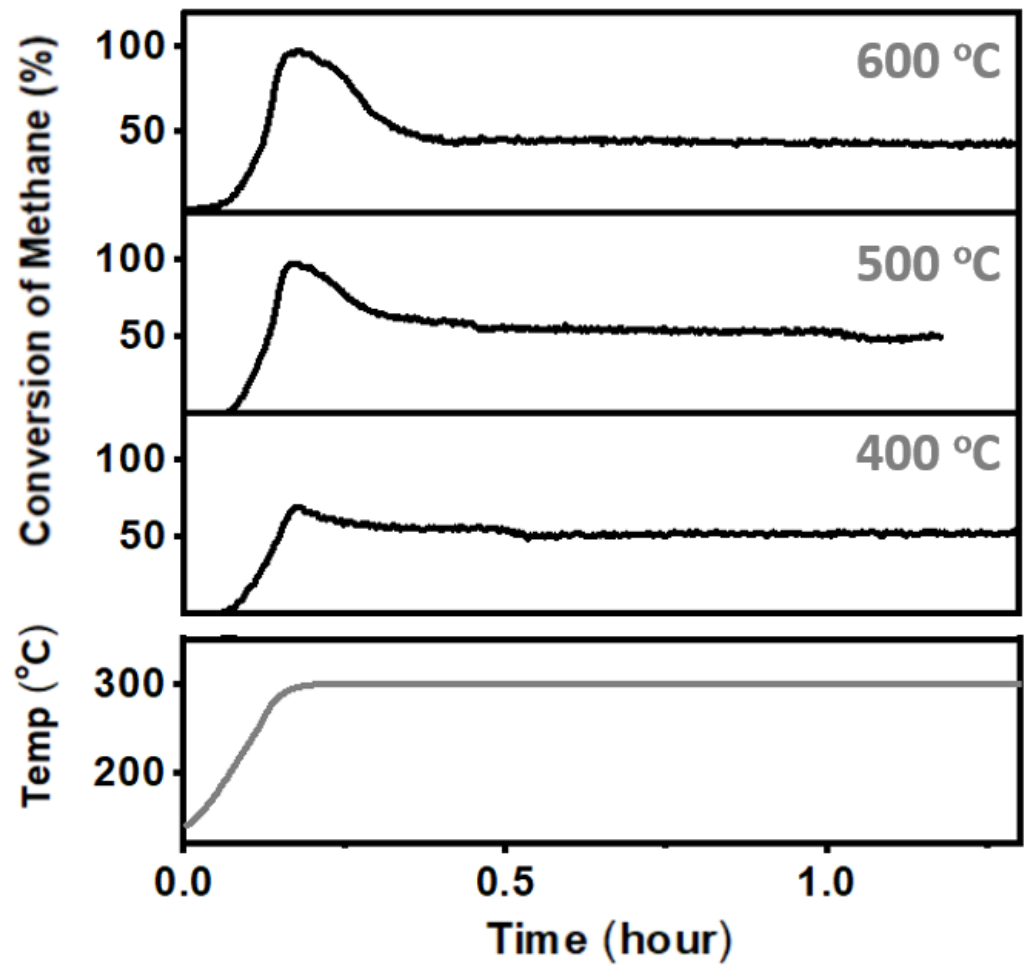

Figure S6. Methane conversion over $\mathrm{Pd} / \mathrm{CeO}_{2}$ diluted with low-surface-area $\mathrm{Al}_{2} \mathrm{O}_{3}$ up to $300{ }^{\circ} \mathrm{C}$, in which $\mathrm{Al}_{2} \mathrm{O}_{3}$ was pretreated in-situ at $400{ }^{\circ} \mathrm{C}, 500{ }^{\circ} \mathrm{C}$ and $600{ }^{\circ} \mathrm{C}$, respectively. 


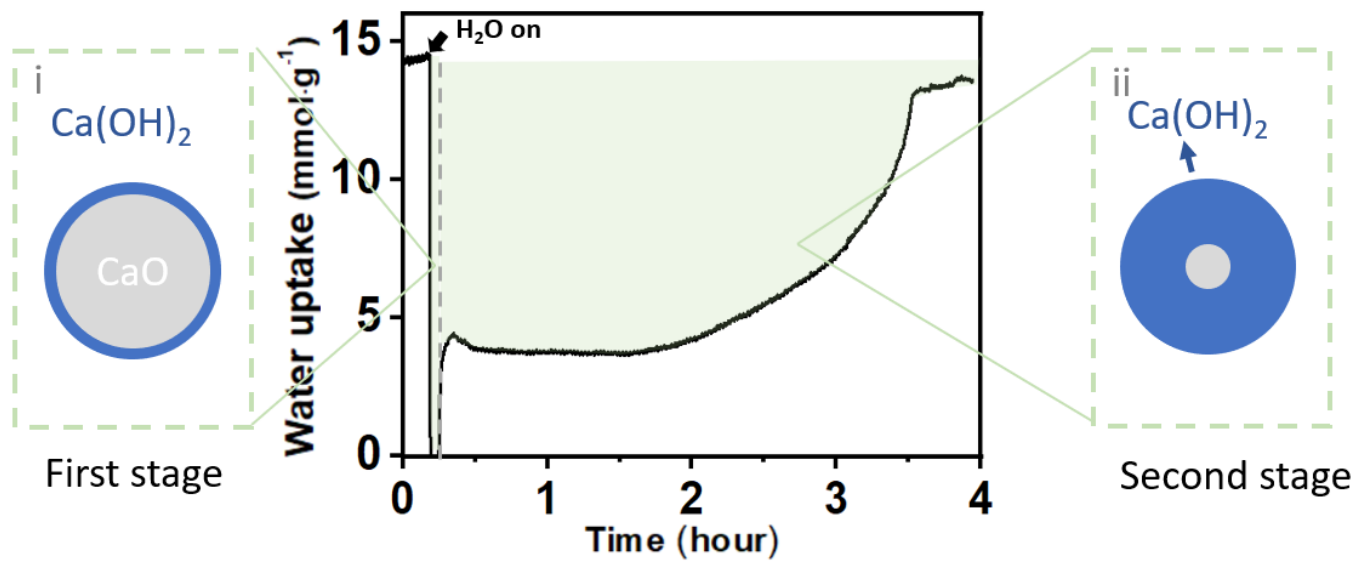

Figure S7. $\mathrm{H}_{2} \mathrm{O}$ uptake of pure $\mathrm{CaO}$ at $300{ }^{\circ} \mathrm{C}$ under a 4.2 vol. $\% \mathrm{H}_{2} \mathrm{O}$ flow (in Ar). At the end of the first stage, the growth of a $\mathrm{Ca}(\mathrm{OH})_{2}$ product layer in the latter stage leads to significantly slower diffusion of $\mathrm{H}_{2} \mathrm{O}$. The experimentally measured water sorption capacity is about $0.83 \mathrm{~mol} / \mathrm{mol}$, which is close to the theoretical value of $1 \mathrm{~mol} / \mathrm{mol}$. 


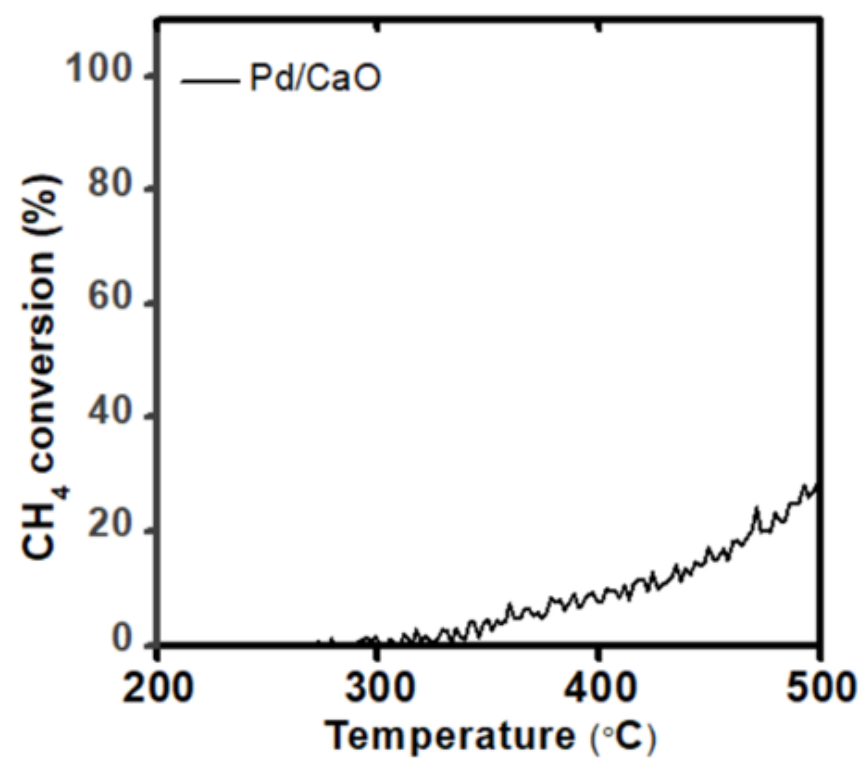

Figure S8. Methane combustion over $\mathrm{Pd} / \mathrm{CaO}$. 


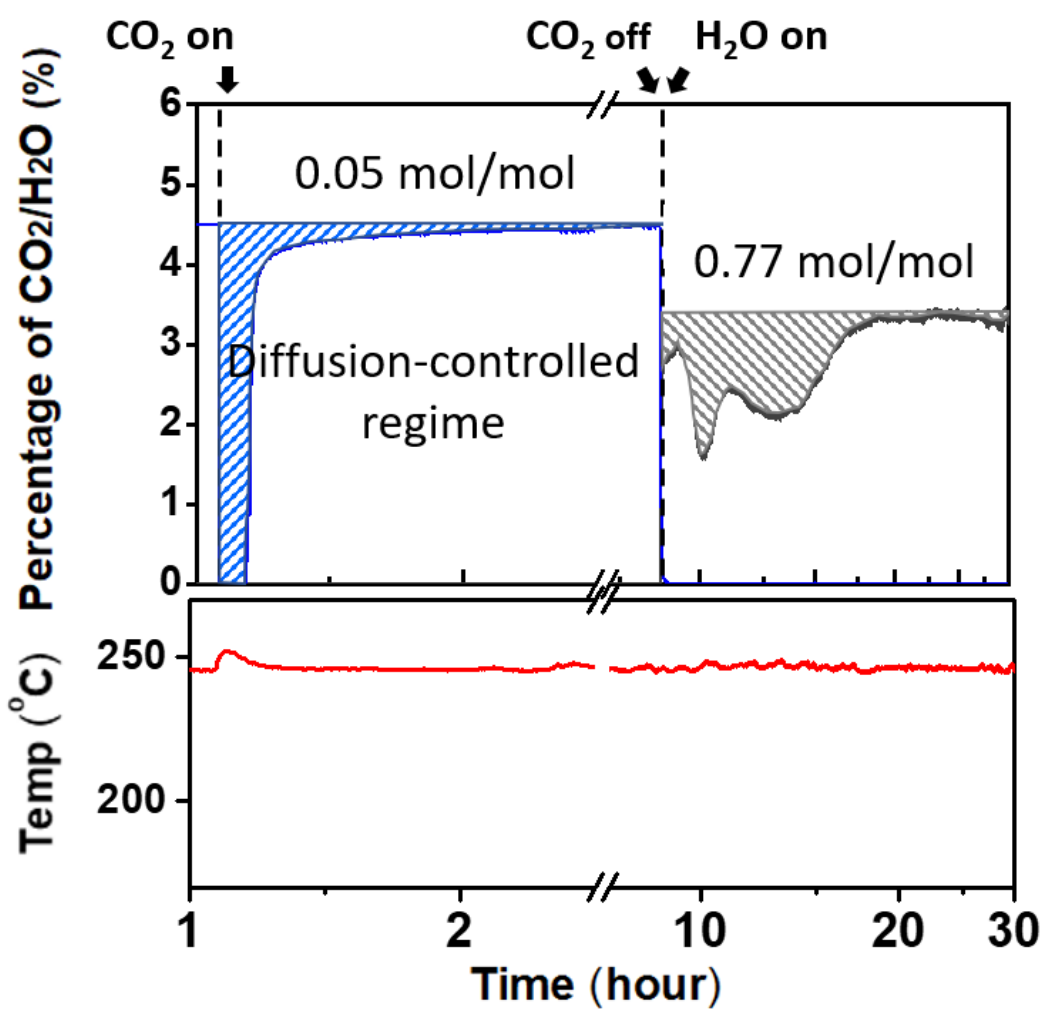

Figure S9. Time-dependent experiment on $360 \mathrm{mg}$ pure $\mathrm{CaO}$ nanoparticle at $245^{\circ} \mathrm{C}$ with the follow of $5 \% \mathrm{CO}_{2}$ (in $\mathrm{Ar}$ ) and $4.2 \% \mathrm{H}_{2} \mathrm{O}$ (in Ar) sequentially. 

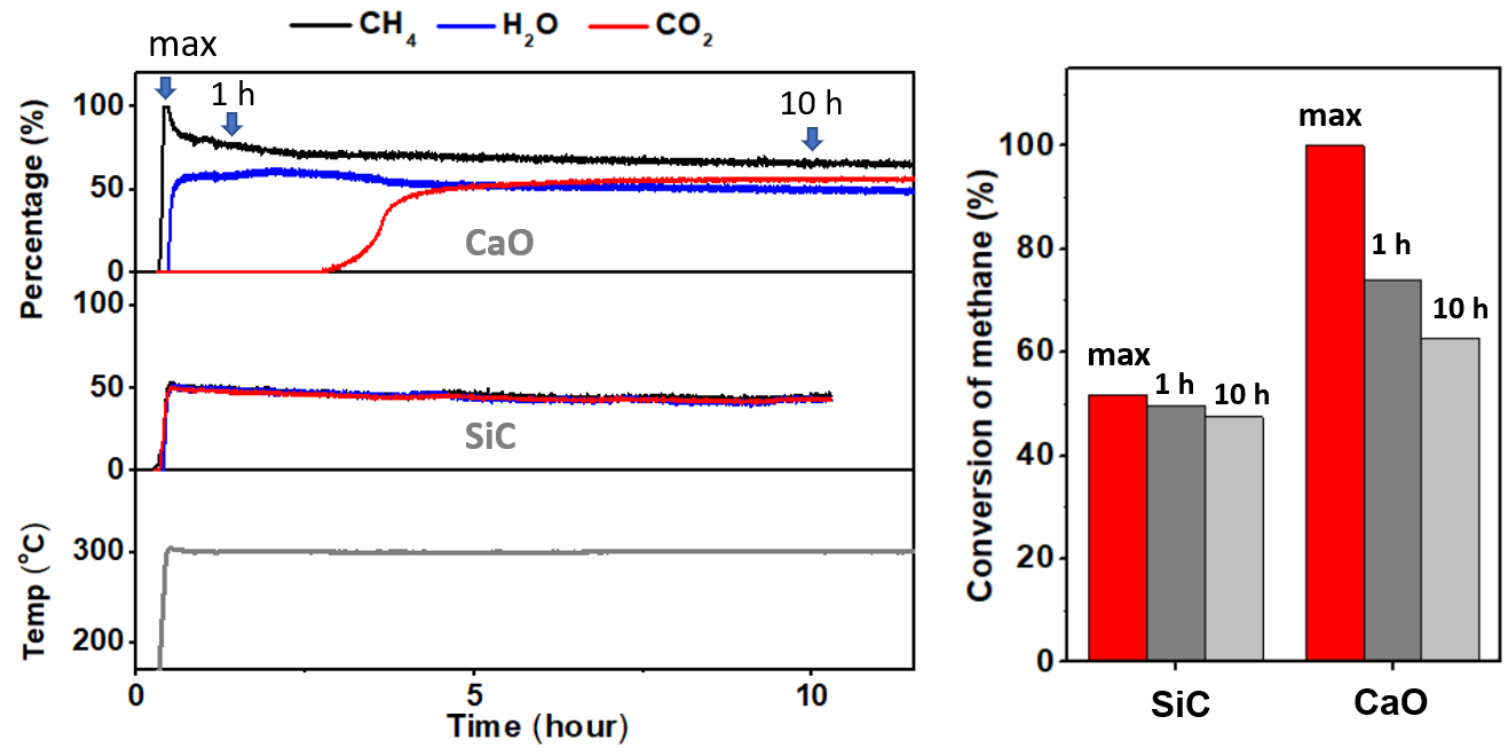

Figure S10. Methane conversion over $\mathrm{Pd} / \mathrm{CeO}_{2}$ diluted with $\mathrm{CaO}(360 \mathrm{mg}, 6.4 \mathrm{mmol})$ at $300{ }^{\circ} \mathrm{C}$ for $10 \mathrm{~h}$. The total gas flow rate was $23.5 \mathrm{~mL} \mathrm{~min}^{-1}$, consisting of $\mathrm{CH}_{4}(0.4 \%)$ and $\mathrm{O}_{2}(4.0 \%)$ diluted in Ar. The total measured $\mathrm{H}_{2} \mathrm{O}$ and $\mathrm{CO}_{2}$ sorption is about $1.68 \mathrm{mmol}$ $\left(0.26 \mathrm{~mol} \mathrm{H}_{2} \mathrm{O}\right.$ per mol of $\left.\mathrm{CaO}\right)$ and $1 \mathrm{mmol}\left(0.16 \mathrm{~mol} \mathrm{CO}_{2}\right.$ per mol of $\left.\mathrm{CaO}\right)$, which indicates $\mathrm{CaO}$ sorbent is not saturated after the test. Note that $1 \mathrm{~mol}$ methane produces 2 mol $\mathrm{H}_{2} \mathrm{O}$ and $1 \mathrm{~mol} \mathrm{CO}_{2}$. Even if the yield of $\mathrm{H}_{2} \mathrm{O}$ and $\mathrm{CO}_{2}$ are the same at the fifth hour $(50 \%)$, the sorption of $\mathrm{H}_{2} \mathrm{O}$ by $\mathrm{CaO}$ is still 2 times higher than that of $\mathrm{CO}_{2}$. 


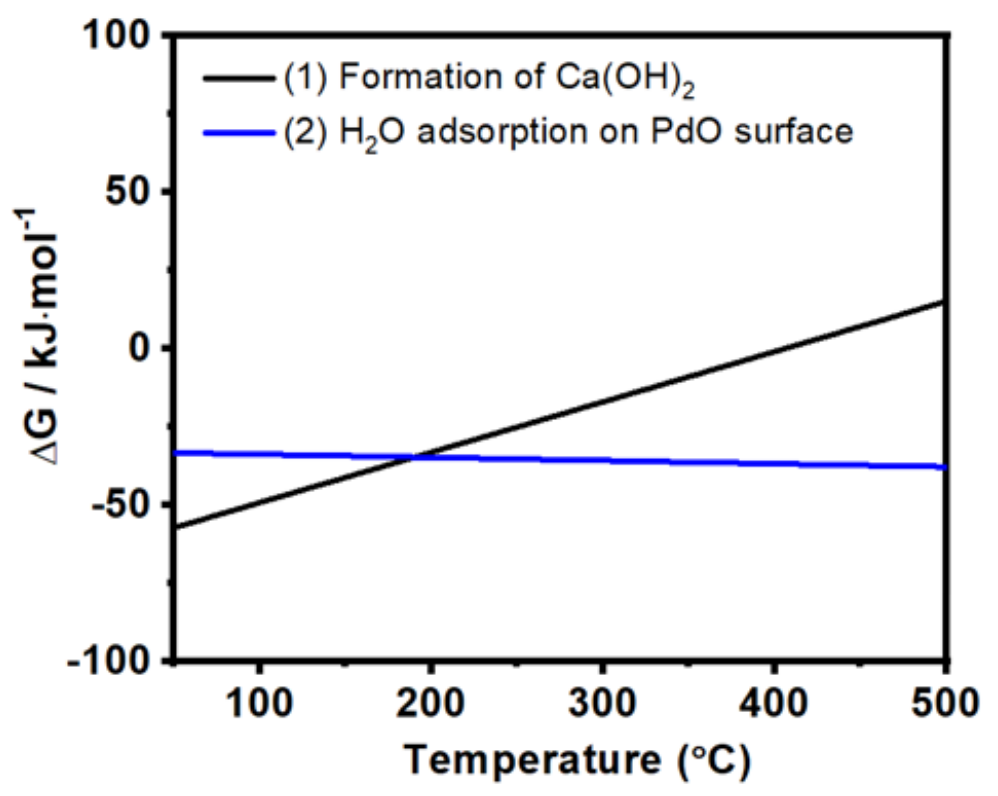

Figure S11. $\Delta \mathrm{G}(\mathrm{T})$ of different bulk and surface reactions in the temperature range of the catalytic methane oxidation. 


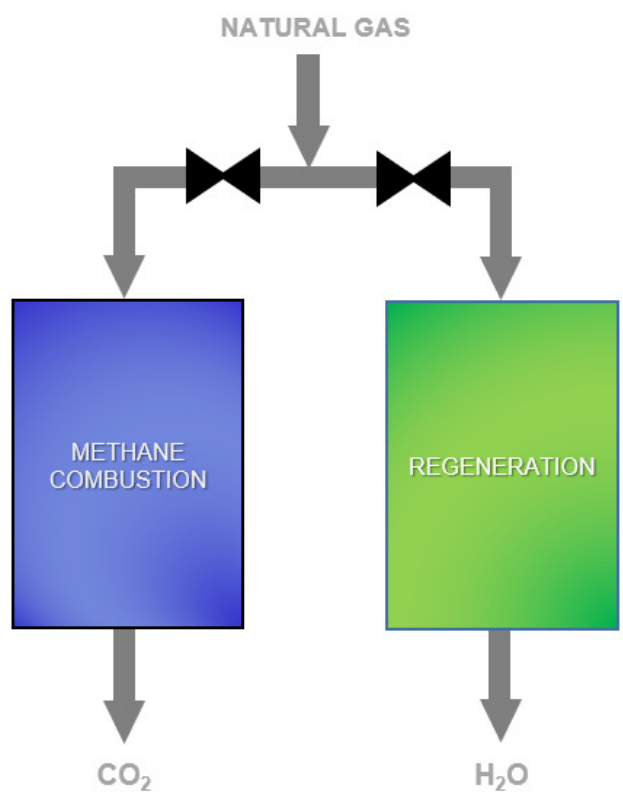

Figure S12. Schematic of methane combustion reactor switching system, where an additional catalyst is used for the reaction while the deactivated catalyst is regenerated at the same time. 
Table S1. Values of $\mathrm{CH}_{4}$ consumption and $\mathrm{H}_{2} \mathrm{O}$ production in regime I, and values for $\mathrm{H}_{2} \mathrm{O}$ uptake from TPD experiment.

\begin{tabular}{|c|c|c|c|}
\hline & $\mathrm{CH}_{4}$ consumption & $\mathrm{H}_{2} \mathrm{O}$ production ${ }^{\mathrm{a}}$ & $\mathrm{H}_{2} \mathrm{O}$ uptake $^{\mathrm{b}}$ \\
\hline Sample & $(\mu \mathrm{mol})$ & $(\mu \mathrm{mol})$ & $(\mu \mathrm{mol})$ \\
\hline $\mathrm{SiC}$ & 1.1 & 2.1 & 0 \\
\hline H-Beta & 6.1 & 12.2 & 2.3 \\
\hline $\mathrm{H}-\mathrm{Y}$ & 9.3 & 18.6 & 14.6 \\
\hline H-ZSM5 & 10.7 & 21.4 & 35.1 \\
\hline \multicolumn{4}{|l|}{$\mathrm{Al}_{2} \mathrm{O}_{3}, 104$} \\
\hline $\mathrm{m}^{2} / \mathrm{g}$ & 28.6 & 57.2 & 65.4 \\
\hline \multicolumn{4}{|l|}{$\mathrm{Al}_{2} \mathrm{O}_{3}, 360$} \\
\hline $\mathrm{m}^{2} / \mathrm{g}$ & 35.5 & 71 & 111.1 \\
\hline $\mathrm{CaO}$ & 44.9 & 89.8 & 140.9 \\
\hline
\end{tabular}

aThe values are calculated from $\mathrm{CH}_{4}$ consumption; ${ }^{\mathrm{b}}$ The $\mathrm{H}_{2} \mathrm{O}$ signal between $300-500{ }^{\circ} \mathrm{C}$ was integrated for zeolites, while the surface adsorptive sites were considered for $\mathrm{CaO}$ 


\section{The calculation of Gibbs free energy change}

The enthalpy of $\mathrm{H}_{2} \mathrm{O}$ adsorption of $\mathrm{PdO}$ was calculated following previously published procedures with small modification. ${ }^{1}$ A reaction model based on the following assumptions was used to study the $\mathrm{H}_{2} \mathrm{O}$ inhibiting effect: (1) methane dissociative adsorption on PdO surface is the rate-limiting step. Methane dissociatively and irreversibly adsorbs on the surface of $\mathrm{PdO}$ and is further consumed promptly, which leads to the zero coverage of methane on the $\mathrm{PdO}$ surface. (2) The $\mathrm{H}_{2} \mathrm{O}$ inhibiting effect is caused by adsorption of $\mathrm{H}_{2} \mathrm{O}$ on the surface of $\mathrm{PdO} . \mathrm{H}_{2} \mathrm{O}$ adsorption onto and desorption from $\mathrm{PdO}$ surface reaches equilibrium. (3) The coverage of $\mathrm{CO}_{2}$ on the surface of $\mathrm{PdO}$ is zero, due to the rapid desorption of $\mathrm{CO}_{2}$ formed by methane combustion. The kinetic equations could be derived as below:

The kinetic equations could be derived as below:

$$
r=k_{r}\left[\mathrm{CH}_{4}\right] \theta_{V}
$$

where $r$ is the methane oxidation reaction rate, $\left[\mathrm{CH}_{4}\right]$ is the concentration of methane, $\theta_{V}$ is the fraction of vacancies on $\mathrm{PdO}$ surface and $k_{r}$ is the surface methane combustion rate constant, which could be further calculated by the equation:

$$
k_{r}=K_{1} \exp \left(\frac{-E_{A}}{R T}\right)
$$

where $K_{1}$ is the pre-exponential factor, $E_{A}$ is the activation energy, $R$ is the gas constant and $T$ is the temperature.

$\theta_{V}$ could be further calculated using the following equation, where $\theta_{\mathrm{H}_{2} \mathrm{O}}$ represents the fractional occupancy of $\mathrm{H}_{2} \mathrm{O}$ on the adsorption sites:

$$
\theta_{V}=1-\theta_{\mathrm{H}_{2} \mathrm{O}}=1-\frac{K_{\mathrm{H}_{2} \mathrm{O}}\left[\mathrm{H}_{2} \mathrm{O}\right]}{1+K_{\mathrm{H}_{2} \mathrm{O}}\left[\mathrm{H}_{2} \mathrm{O}\right]}=\frac{1}{1+K_{\mathrm{H}_{2} \mathrm{O}}\left[\mathrm{H}_{2} \mathrm{O}\right]}
$$


where $\left[\mathrm{H}_{2} \mathrm{O}\right]$ is the concentration of $\mathrm{H}_{2} \mathrm{O}, K_{\mathrm{H}_{2} \mathrm{O}}$ is the adsorption equilibrium constant, which can be expressed as:

$$
K_{H_{2} O}=K_{2} \exp \left(\frac{-\Delta H_{a d s}}{R T}\right)
$$

where $\Delta H_{a d s}$ represents enthalpy of $\mathrm{H}_{2} \mathrm{O}$ adsorption on $\mathrm{PdO}$ surface and $K_{2}$ is the pre-exponential factor. And the expression of methane oxidation rate becomes:

$$
r=\frac{k_{r}(1-x)\left[\mathrm{CH}_{4}\right]_{0}}{1+K_{\mathrm{H}_{2} O}\left(\left[\mathrm{H}_{2} \mathrm{O}\right]_{0}+2 x\left[\mathrm{CH}_{4}\right]_{0}\right)}
$$

In the above equation, $\left[\mathrm{CH}_{4}\right]_{0}$ and $\left[\mathrm{H}_{2} \mathrm{O}\right]_{0}$ represent the initial concentration of methane and $\mathrm{H}_{2} \mathrm{O}$ in the feed, $x$ represents the fraction of methane conversion. The reaction rate $r$ under wet condition estimated from methane conversion less than $10 \%$ was fitted into the equation above to calculate the $\mathrm{H}_{2} \mathrm{O}$ adsorption equilibrium constant $K_{\mathrm{H}_{2} \mathrm{O}}$ at different temperatures. The activation energy $E_{A}$ and $K_{1}$ the pre-exponential factor are calculated from Arrhenius fit of the experimental results under dry condition, with which the surface methane combustion rate constant $k_{r}$ can be determined. The reaction rate $r$ under wet condition, the surface methane combustion rate constant $k_{r}$ calculated under dry condition, the fraction of methane conversion $x$, and the initial concentration of methane and $\mathrm{H}_{2} \mathrm{O}\left[\mathrm{CH}_{4}\right]_{0}$ and $\left[\mathrm{H}_{2} \mathrm{O}\right]_{0}$ were substitute into the equation of methane oxidation rate to give $K_{\mathrm{H}_{2} \mathrm{O}}$. The data sets $\left(1 / \mathrm{T}, \ln K_{\mathrm{H}_{2} \mathrm{O}}\right.$.) were fitted with a linear function to get the slope $\left(\frac{-\Delta H_{a d s}}{R}\right)$, with which the enthalpy of $\mathrm{H}_{2} \mathrm{O}$ adsorption on $\mathrm{PdO}$ surface, $\Delta H_{a d s}$ was calculated to be $-30.0 \mathrm{~kJ} / \mathrm{mol}$. We refer the adsorption entropy to a reported literature, where the entropy of $\mathrm{H}_{2} \mathrm{O}$ adsorption on silica was calculated to be $10.3 \mathrm{~J} / \mathrm{mol} \cdot \mathrm{K} .^{2}$ The change of Gibbs free energy of $\mathrm{H}_{2} \mathrm{O}$ adsorption on $\mathrm{PdO}$ at $573 \mathrm{~K}$ was $-35.9 \mathrm{~kJ} / \mathrm{mol}$. 
We also determined the change of Gibbs free energy of $\mathrm{H}_{2} \mathrm{O}$ adsorption on $\mathrm{PdO}$ at $573 \mathrm{~K}$ according to a published literature, where a DFT study was conducted to calculate the reaction energies for different reactions which are or could be involved in the combustion of methane on $\mathrm{PdO} .{ }^{3}$ The energy of $\mathrm{H}_{2} \mathrm{O}$ molecule desorption from $\mathrm{PdO}$ at 573 $\mathrm{K}$ was calculated to be $0.40 \mathrm{eV}$. Thus, the Gibbs free energy change of $\mathrm{H}_{2} \mathrm{O}$ adsorption on $\mathrm{PdO}$ at $573 \mathrm{~K}$ was $-38.5 \mathrm{~kJ} / \mathrm{mol}$, similar with the result calculated above.

The Gibbs free energy of the formation of $\mathrm{Ca}(\mathrm{OH})_{2}$ from $\mathrm{CaO}$ was calculated from standard enthalpy of formation and conventional entropy of $\mathrm{CaO}, \mathrm{H}_{2} \mathrm{O}$ and $\mathrm{Ca}(\mathrm{OH})_{2}$. The thermodynamic parameters mentioned above are summarized in Table S2. 
Table S2. Thermodynamic parameters of $\mathrm{H}_{2} \mathrm{O}$ adsorption

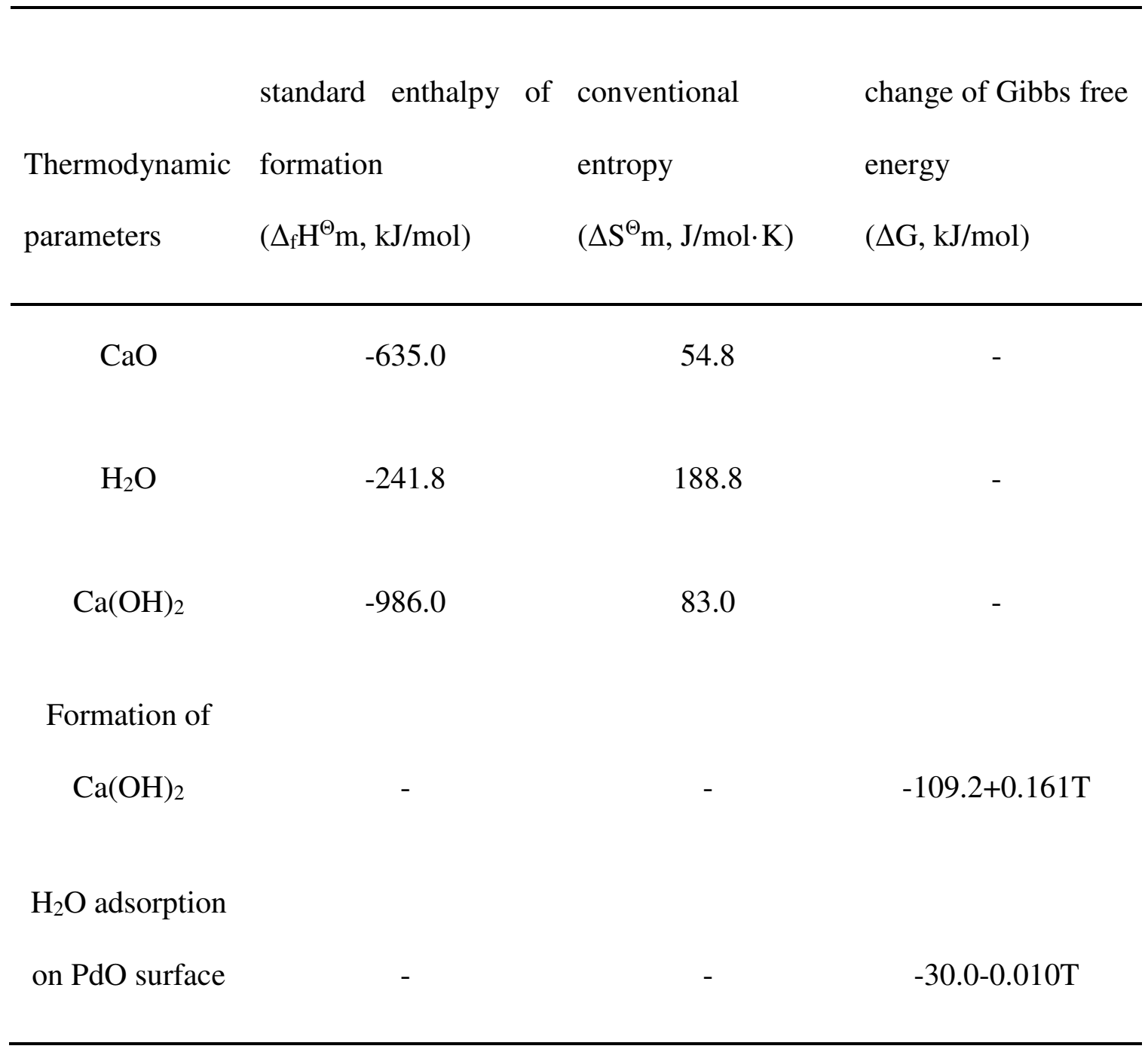

\section{The calculation of $\mathrm{PdO}$ and $\mathrm{CaO}$ surface adsorptive sites}

The accessible sites on $\mathrm{CaO}$ surface are computed from atomic-scale structure. The arrangement of ions of calcium oxide is the same as sodium chloride crystals, with oxygen ions forming a face-centered cubic (FCC) cell and calcium ions located in the octahedral interstitials in the middle of the cell edges and at the center of the cell, which leads to the close contact of the neighboring calcium ions and oxygen ions. We assumed the radius of 
$\mathrm{Ca}^{2+}$ and $\mathrm{O}^{2-}$ to be $1.0 \AA$ and $1.4 \AA$ respectively and further compute the edge length of unit cell to be $4.8 \AA$. Knowing the surface area of $\mathrm{CaO}\left(25 \mathrm{~m}^{2} / \mathrm{g}\right)$, the number of lattice planes on surface per gram can be calculated. We assumed that two $\mathrm{Ca}^{2+}$ and two $\mathrm{O}^{2-}$ are located on one lattice plane, the accessible sites can then be calculated. The calculation of sites can be derived as follows:

$$
\begin{gathered}
a=2 \times\left(r_{C a^{2+}}+r_{O^{2-}}\right) \\
A=a^{2} \\
N_{\text {planes }}=\frac{S_{B E T}}{A} \\
N_{\text {sites }}=2 \times N_{\text {planes }}
\end{gathered}
$$

where a is the edge length of unit cell, ${ }^{\mathrm{Ca}_{\mathrm{C}^{2+}}}$ and ${ }^{\mathrm{r}_{\mathrm{O}^{2-}}}$ are the radius of calcium ions and oxygen ions respectively, A is surface area of lattice plane, $N_{\text {planes is }}$ the number of lattice planes on surface per gram and $N_{\text {sites }}$ is the number of accessible sites per gram.

The calculation of accessible sites on $\mathrm{PdO}$ surface is very similar to the $\mathrm{CaO}$ case. Since the surface area of $\mathrm{Pd} / \mathrm{CeO}_{2}$ was calculated via $\mathrm{CO}$ chemisorption and $\mathrm{CO}$ could only adsorb on the surface of metallic Pd, the accessible sites were calculated in terms of Pd sites. We assumed that the surface sites accessible to $\mathrm{H}_{2} \mathrm{O}$ of $\mathrm{Pd}$ remained after oxidized to PdO. Considering the arrangement of atoms of metallic Pd is face-centered cubic (FCC), the atoms on the diagonal of face are in contact with each other. Knowing the radius of Pd atom $(1.37 \AA)$ and surface area $\left(0.80 \mathrm{~m}^{2} / \mathrm{g}\right)$, the number of lattice planes on surface per gram can be calculated. We assumed that two Pd atoms are located on one lattice plane, the accessible sites can then be calculated. The calculation of sites can be derived as follows: 


$$
\begin{gathered}
a=2 \sqrt{2} \times\left(r_{P d}\right) \\
A=a^{2} \\
N_{\text {planes }}=\frac{S_{B E T}}{A} \\
N_{\text {sites }}=2 \times N_{\text {planes }}
\end{gathered}
$$

Where $r_{P d}$ represents the radius of Pd atoms, other denotations are the same as above.

The accessible sites on $\mathrm{Al}_{2} \mathrm{O}_{3}$ was computed based on the $\mathrm{H}_{2} \mathrm{O}$ uptake measured via $\mathrm{H}_{2} \mathrm{O}$-TPD. The $\mathrm{H}_{2} \mathrm{O}$ uptake has been computed to be 70 and $111.1 \mu \mathrm{mol}$ for large-surface $\mathrm{Al}_{2} \mathrm{O}_{3}$ and high-surface $\mathrm{Al}_{2} \mathrm{O}_{3}$ respectively. The total sites can be computed as below:

$$
N_{\text {sites }}=\frac{n \times N_{A}}{m_{\text {diluents }}}
$$

where $N_{\text {sites }}$ is the number of accessible sites per gram, $n$ is $\mathrm{H}_{2} \mathrm{O}$ uptake, $N_{A}$ is Avogadro constant, $m_{\text {diluents }}$ is the mass of diluents.

The total sites of diluents could be calculated as below:

$$
N_{\text {total,diluent }}=N_{\text {sites,diluents }} \times m_{\text {diluents }}
$$

The total sites of $\mathrm{PdO}$ could be calculated as below:

$$
N_{\text {total }, P d o}=N_{\text {sites }, P d o} \times m_{P d o} \times W_{P d o}
$$

$W_{P d o}$ represents the weight loading of $\mathrm{PdO}$

The number of total accessible sites calculated above are summarized in Table S3. 
Table S3. The number of accessible sites

\begin{tabular}{lc}
\hline & the number of accessible sites \\
\hline $\mathrm{PdO}$ & $2.14 \times 10^{15}$ \\
$\mathrm{CaO}$ & $7.81 \times 10^{19}$ \\
\hline
\end{tabular}

Table S4. The measured $\mathrm{H}_{2} \mathrm{O}$ and $\mathrm{CO}_{2}$ sorption in each cycle of the regeneration experiment.

\begin{tabular}{ccc}
\hline & $\begin{array}{c}\mathrm{Absorbed} \mathrm{H}_{2} \mathrm{O} \\
(\mathrm{mmol})\end{array}$ & $\begin{array}{c}\text { Absorbed } \mathrm{CO}_{2} \\
(\mathrm{mmol})\end{array}$ \\
\hline 1st cycle & 0.22 & 0.12 \\
2nd cycle & 0.20 & 0.09 \\
3rd cycle & 0.23 & 0.10 \\
\hline
\end{tabular}

\section{REFERENCES}

(1) Kikuchi, R.; Maeda, S.; Sasaki, K.; Wennerström, S.; Eguchi, K. Low-Temperature Methane Oxidation over Oxide-Supported Pd Catalysts: Inhibitory Effect of Water Vapor. Appl. Catal. A Gen. 2002, 232, 23-28.

(2) Chakraborty, A.; Saha, B. B.; Koyama, S.; Ng, K. C.; Srinivasan, K. Adsorption Thermodynamics of Silica Gel-Water Systems. J. Chem. Eng. Data 2009, 54, 448452 .

(3) Dianat, A.; Seriani, N.; Ciacchi, L. C.; Bobeth, M.; Cuniberti, G. DFT Study of Reaction Processes of Methane Combustion on PdO(100). Chem. Phys. 2014, 443, 53-60. 